\title{
Historical Comics' Development of Babad Wirasaba to Improve Senior High School Students' Historical Awareness in Purbalingga
}

\author{
Handika Samito Aji ${ }^{1}$, Nunuk Suryani ${ }^{2}$, Warto Warto ${ }^{3}$ \\ ${ }^{1}$ History Education, Master Degree of Teacher Training and Education Faculty, Universitas \\ Sebelas Maret Surakarta \\ ${ }^{2}$ Educational Technology, Master Degree of Teacher Training Education Faculty, Universitas \\ Sebelas Maret Surakarta \\ ${ }^{3}$ Historical Science, Faculty of Cultural Science, Universitas Sebelas Maret Surakarta \\ e-mail: h4ndik4_sazt@yahoo.co.id
}

\begin{abstract}
The purpose of this research is (1) analyzing the level of awareness of the history of the students and the use of learning media history at SMA Purbalingga, (2) Develop media comics history Chronicle Wirasaba (3) to evaluate the effectiveness of the use of the history of the Chronicle Wirasaba comic media to increase awareness of students to the values of history.

The study is a Reasearch and Development (R\&D) that using ADDIE model by Molenda's. This model consists of five stages. These five stages include preliminary studies, development of instructional media, and the test of effectiveness of the intructional media. Product testing was performed on the stage of development at SMA Negeri 1 Kemangkon. The test phase of the experiment conducted at SMA Negeri 1 Bukateja. Feasibility data analysis model using a Likert scale ranging from 1 to 5, while the effectiveness test model using Independent Sample T Test in SPSS.

The results of the study showed that, (1) the level of awareness of the history of high school students in Purbalingga still low. The students in the teaching and learning process require media or independent learning resources that are able to increase awareness of the history of the comic history. (2) The result of the validation media with average value of 4.95 (criteria for good), and the average value of material validation is 4.25 (good criteria) (3) Test the effectiveness with one control class and one class experiment concluded that $\mathrm{H}_{0}$ rejected or there is a difference between the average of the class experiments and control classes so that the comic is proven to be effective to increase the level of awareness of students.
\end{abstract}

\section{Keywords: comics history wirasaba; comics history; chronicle wirasaba}

\section{INTRODUCTION}

Education as the existence controller of local values in the current globalization era has faced hard and difficult challenges. The globalization era of is an era where time, space, and distance are no longer a barrier. Globalization affects on the change of cultural values of a nation that slowly shifts the exist values. According to Irwan 
Abdullah [1] Global culture is characterized by the integration of local culture into a global order. The diverse cultural values become the basis for forming the independent sub-cultures with freedoms of expression.

Nowadays, young people have lived alongside with globalization. Globalization is certainly like a double-edged knife for the young generation. On the one side, it is safe but on the other side is very dangerous. The positive things from globalization that can be realized are helping and facilitating us in communicating, gaining knowledge and insight widely, being able to interact with other outsiders, being able to facilitate us in business, and being able to know the quality and competitiveness of other communities either outside or inside. Azizy [2] states that if globalization does give positive things, values and practices that does not settle conflict with local, national, and especially religious values, it should be a challenge for Indonesia to be able to absorb it.

The increasingly threatening effect of globalization for the identity of a nation is much pitied. The young generation who over-glorified the more popular cultures made the local culture is getting eliminated. Even, the young generation is not familiar with the history of the nation and local culture of the hometown. It is evidenced from the results of interviews with the students of SMA Negeri 1 Bukateja on August 10, 2016. Many students do not know what the history of wirasaba, the history of onje, and the history of perdikan cahyana are. The difficulty of local culture in Purbalingga becomes something popular among the successors of the nation got very tough challenges.

The history of Kadipaten Wirasaba was great in the area that became one of the villages in Purbalingga which has begun to disappear. The inheritance of this Kadipaten is the Babad script that has been passed down from generation to generation, petilasan pendopo, heirloom grave and Adipati Wargautama's clothing. The script of babad wirasaba was copied the last time in 1956 by Mulyorejo [3]. The original script was written 1858 with candra sengkala swara naga giri nabi (Mad Marta, 2016). Unfortunately, the successor of Babad Wirasaba who was supposed to be an heir, was no longer able to continue as the babad expert.

Based on the results of preliminary observations in SMA N 1 Bukateja and SMA Negeri 1 Kemangkon, many students did not know a lot about the history except for those who live in the petilasan environment, and even only half of them, not all the young generation knew that the origin of Banyumas Residency started from Wirasaba. The Wirasaba history should be introduced to the young generation. In the teaching and learning activities, students are very rarely introduced about the local history that exist in the Purbalingga region. Most of them are only introduced how the national history of resistance against colonialism, while local history that became local wisdom of Purbalingga had just forgotten.

An effective learning process must apply the correct model and design of learning. Heneich, Molenda, Russell \& Smaldino (1996: 8) state the process of delivering learning materials to students is heavily influenced by the media, and the tools needed by students to learn. Muhibbin Shah (1995: 132) identifies the factors that influence learning is internal factors, external factors, and learning approach factors. Internal factors are the condition of students' physical and spiritual. External factors are environmental conditions around students. Learning approach factors are the types of students' learning efforts that include strategies and methods used by students to conduct learning activities. 
Based on the description, it can be described the problems in the lack of local history awareness to the young generation in Purbalingga. Through the less interesting of historical learning done in teaching learning process in high school, researcher will develop comic media as a learning resource. The researcher will develop the historical comic of Babad Wirasaba to increase the awareness of local history towards High School Students in Purbalingga. The purpose of this research and development is to assess the effectiveness of the usage of Babad Wirasaba historical comic media to increase students' awareness of historical values.

\section{RESEARCH METHOD}

Research conducted is development research (Research and Development) using the model of ADDIE from Molenda [4]. The stages in this development are (1) Analysis, analysing the needs of KI / KD with media (2) Design, making the comic planning how to make and the things used in the making process, (3) Development, the development process of the early draft of the comic before doing the validation test by the experts, (4) Implementation, this process is the class implementation whether the media has been able to be adapted and implemented well in the class (5) evaluation, this process is a process of test by doing the achievement test in large group or a broad group. Object in this research to implementasi and evaluasi is Class $\mathrm{X}$ B, SMA Negeri 1 Kemangkon. The process can be drawn with a hypothetical model for the development process to be seen clearly and easily understood. 


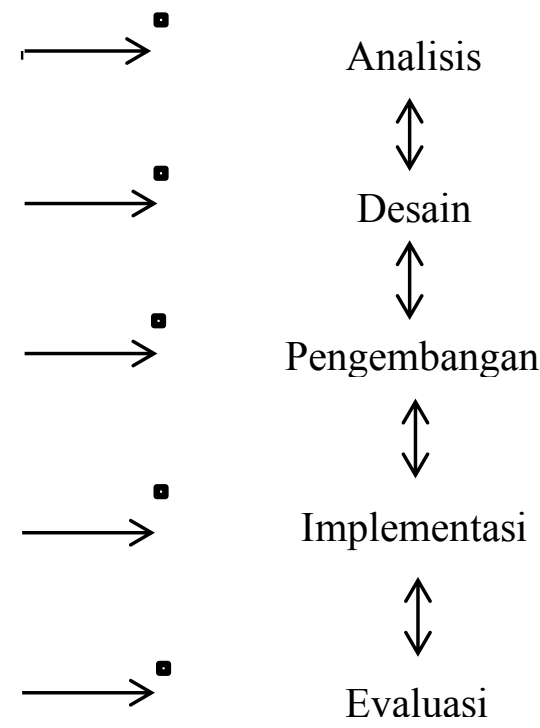

Figure 1. The development hypothetical model of the comic of ADDIE model comic

The development research using the ADDIE model proved successful is the development of historical comic media of Raden Intan I struggle-based to improve the students' nationalism at SMA Negeri 1 Tanjung Raya by Beny Iswandono. The comic proved successful in its development using the ADDIE model as well as the development of this wirasaba historical comic. The process of implementing the comics was successful and proved the effectiveness in enhancing the nationalism values.

This study aims to test the learning media of Babad Wirasaba historical comic. The population of this research is the students of SMA Negeri 1 Bukateja. It will be selected two classes as controlled class and experimental class from six classes of social science program. The determination of the experimental and controlled classes was conducted by using pre-test of achievement and attitude.

In this study, there was a different treatment between the experimental group and the controlled group. The teaching and learning process in experimental groupused the learning resource of Babad Wirasaba historical comic. Meanwhile, the teaching and learning process in controlled class used conventional methods that is lectures as usual. There are 3 stages in the study that will be conducted to be able to express thoroughly related to the problems posed in this study, they are: 1) The initial stage of the experiment, 2) The implementation stage of the experiment, 3) The final stage of the experiment. The data required in this study is the average value of the attitudes of students' historical awareness. Students' attitudes were measured by using a questionnaire filling method. The measurement instrument of the attitude value of students' historical awareness towards students of SMA Negeri 1 Bukateja amounted 30 questions.

The learning design was concerned with the process that determined the learning objectives, strategies and techniques to achieve the goals as well as to design the media used for the effectiveness of goal achievement (Wina Sanjaya, 2012: 65). This research adopted ADDIE development design. The subjects of the study were students of SMA Negeri 1 Bukateja class X IPS 4. The number of students used in the experimental class was 32 students. 
And then, roadworthiness test the effectiveness of to that class of control and class experiment. For the class control brought a X IPS 4, and class experiment a X IPS 3, SMA Negeri 1 Bukateja, Purbalingga. Testing done with compare in value pre- test and post test. An Instrumen use chief awareness history. Testing SPSS use the Independent Sample T test.

\section{DEVELOPMENT WITH MODEL ADDIE}

The development used the modified ADDIE model into several stages, the researcher analysed the teachers' needs to face the existing problems before entering the ADDIE model stage. Then, the independent learning source was chosen which was expected to increase the awareness of the students' local history i.e. the historical comic. Furthermore, it was used ADDIE model with several stages in the development stage. The following stages are:

\section{Analysis}

The product produced in the development of learning media is a comic book. Comic books are chosen because they have a unique compared to other learning media. According to Sudjana (2007: 68) explains, based on the characteristic, the educational comic media has a simple, clear, character and easily understood by students. In addition, comic in education is educative and creating elements of delivering clear and communicative messages. This historical comic media contains about Babad Wirasaba. The target of this historical comic development is the student of class X IPS. Therefore, some aspects such as the suitability of the material with the curriculum and the quality of comics resulted becomes an important point to note. The goal is that the resulting media has a good quality so it will be easily understood by students.

In the early stages of this development design, the first thing that has to do is identify the material to be applied in the learning process. The selected material is accordance to KD on "The Tradition of Pre-Literary and Literary Historical Writing". Basic competence is determining the material to be material in the comic media narrative of "Historical of Babad Wirasaba". The material source was obtained from Babad Wirasaba Mulyorejo version. As a source critic for Babad itself is used for Babad Banyumas version of Wirjaatmadjan and Translation Babad Wirasaba version of Arkakusuma Society.

Source obtained is processed and criticized source in the main source of Wirasaba Babad Mulyorejo version. The result of such processing results in a narrative of reconstructed wirasaba history. The next stage is interpreting each event so it creates an exemplary value without search again for the reader. The process of intrepretation positions the researcher as the author of the chronicle and drifts into the babad author's feelings.

The process of source criticism is the process of separating between fiction and historical facts. Babad becomes a reference for the development of historical comic media is examined and conducted external and internal criticism. Attempts to seek truth, historians are confronting with the need to distinguish what is right, what is not right, what is possible, and what is doubtful or impossible (Syamsudin, 2007: 131). 
This is done because humans must have made a mistake whether intentional or not, sometimes even some who with the false of falsifying documents for political purposes and, etc. Therefore, source of criticism is indispensable in a historical study.

Source criticism is generally done against the first sources. This critique involves verifying the source of testing the truth or accuracy the source. This is in the method of history known by doing external criticism and internal criticism. External criticism relates to the authenticity or originally of the source, by examining the external sources of history, the authenticity of the paper used, the spelling, the style of the language and its writing and all its external appearance (Kuntowijoyo 1995: 101). Manuscript of Wirasaba history is a private or individual collection stored in the village of Wirasaba, District Bukateja, Purbalingga District. The script of Babad Wirasaba History is currently owned by Mad Marta Wirasaba villagers. He is the heir of Mulyorejo as the original owner and copyist of the chronicle. Based on information from Mad Marta, Mulyorejo is an uncle of Mad Marta and he works for the Dutch East Indies government.

Manuscript of Babad Wirasaba history is written in Java letters and Java language. Written on a paper measuring of $16.5 \times 21 \mathrm{~cm}$ with a thickness of 90 pages of manuscripts and details containing 1-85 tembang macapat, while pages 86-90 contains Banyumas pedigree from Duke of Wira Utama (Raden Katuhu) to Raden Tumenggung Yudanegara (Raden Gandakusuma). This manuscript of Wirasaba history contain of 14 poems tembang macapat. In Pupil I and line 2 , there is a description of the time of writing, which is a dispute that sounds swara dragon giri sangi. Based on research from Sugeng Priyadi, the dispute is a mistake to read and copy, should swara dragon giri prophet. Such a denial means the number of Javanese year 1787 saka or 1858 AD. The number is the year of making or writing a script. Mulyorejo was a copyist of the previous manuscript and in the last page of page 90, it is written that Mulyorejo was born on Monday December 27, 1894. The manuscript also had a copy identity by Mulyorejo on August 24, 1956.

Furthermore, internal criticism that the opposite of external criticism. Internal criticism as suggested by its term emphasizes the inner aspect of the source content. Evaluation of the source is conformed to the facts. Researchers should be able to determine whether the contents of the chronicle are a historical or fiction fact. Therefore, it needs the comparison so the information presented can be taken historical facts because the chornicle of fiction values is deeper. The meaning of intent is the babad worships leaders in a region. When viewed from other chapters, then the fiction is expressed by the core chapters is less.

\section{Design}

The process of withdrawing these values will show the values that deserve to be emulated and make high school students become aware of history and participate in keeping history. Narration of the storyline that has been included values of the interpretation process then made a dialogue to facilitate the process of making comics. Dialogue is made as clear as possible and made a storyline that is not bored and easily understood by the reader. The completed dialogue is made into a story board in order to make the process of making perscane more organized and easy. The process of comic description is done by the researchers themselves using coreldraw 
$\mathrm{x} 4$ software. Before entering coreldraw $\mathrm{x} 4$ first sketched on A4 paper and bolded using image pens like Pen Pigma Micron number 04. This is done so in the process of sketch scan to inserted to coreldraw $\mathrm{x} 4$ that more clear and black. If it is using a pencil directly, the sketch will not obvious. The next process is the depiction using coreldraw and character coloring and etc.

\section{Development}

The development process is done carefully and according to the right and good stages. From the making of storyboard followed by the process of making comics based on the design described above. The results of comic creation are followed by validation test. Validation test using experts in the field. Expert material validator test is Prof. Sugeng Priyadi, M. Hum. With an average score of 4.0 while Untung Sugiarto, S.Pd. With an average grade of 3.9. Media expert test validation assisted by Dr. Safe, M.Pd, with an average rating of 4.0 and Dr. Dyah Kumalasari, M.Pd., with the average score is 4.5 . Both tests show average values with both revised and corrected records. It comes from One-to-one testing, small-group testing, and broadgroup testing. The result of the trial got score for one test that is 3.9 small group test scores as much as 10 students that is 3.81 score for big group test is 30 student get score 3.93. The next process is the final settlement of the comic.

\section{Implementation} below:

Display the comic history of babad Wirasaba tested to students can be seen

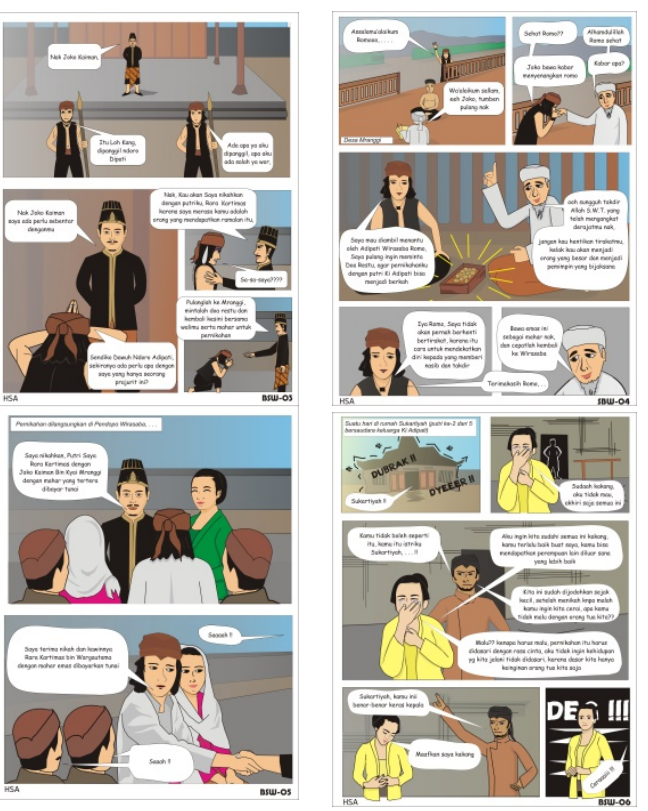

Figure 2. Babad wirasaba historical comic pages 3-6 
Product Implementation process is done in SMA $\mathrm{N} 1$ Kemangkon. Implementation test is done in class and tested whether it can be absorbed by students or not. Teaching and learning process is using comic media and operated by teacher. The learning process is done by class $\mathrm{X}$ sample chapter Writing history during pre-script and literacy period. Learning uses a problem based learning (PBL) model. Classes are divided into 8 groups. Each group consists of 5 students. Source of comic learning is divided into 2 comic books per group. The teacher guides the teaching and learning process to explain the students lacked to understand about the comic content.

\section{Evaluation}

To see the improvement of student achievement, then T test with Paired Samples $\mathrm{T}$ Test. The $\mathrm{T}$ test seeks to compare the positive and significant effects of students' attitudes (pre-test and post-test) before and after treatment. However, before the $\mathrm{T}$ test carried out the requirements that must be completed that the data must be distributed normal and homogeneous. Therefore, normality and homogeneity tests should be performed first. This is the hypothesis of attitude improvement test: Hypothesis :

$\mathrm{H}_{\mathrm{o}}=$ No positive and significant influence before and after treatment

$\mathrm{H}_{1}=$ There is a positive and significant influence before and after treatment is given

Test Decision:

1. If $t$ counts with significance level (2-tailed) $>0.05$ then Ho is accepted and $\mathrm{H}_{1}$ is rejected

2. If $\mathrm{t}$ counts to the level of significance (2-tailed) $<0.05$ then $\mathrm{H} 0$ is rejected and $\mathrm{H}_{1}$ is accepted.

TABLE 1. RESULT OF SPSS CORRELATION ANALYSIS

\begin{tabular}{ccc}
\hline $\mathrm{N}$ & Correlation & Sig. \\
\hline 30 & .321 & .084 \\
\hline
\end{tabular}

TABLE 2. SPSS CALCULATION RESULT PAIRED SAMPLE T TEST

\begin{tabular}{cc}
\hline $\mathrm{t}$ & $\mathrm{Sig}$ \\
\hline-5.517 & 0.000 \\
\hline
\end{tabular}

Based on the above calculation, it is obtained that tcount is -5.517 . The ttable with $\mathrm{df}$ as much as 29 is 2.0452 . The significant value obtained from the above table is 0.000 . Based on the above decision making, it is known that -tcount $>$-ttabel, that is $-5.517>-2.0452$, while significant value $>0.05$, that is $0.00>0.05$. Based on these two comparisons the decision is made that $\mathrm{H}_{0}$ is rejected and $\mathrm{H}_{1}$ accepted. Thus, the decision was made that there were differences in the results of pre-test and post-test of student achievement. The decision is strong and positive because the correlation at the number of 0.321 . 


\section{EFFECTIVENESS TEST}

Effectivenness test comik history of Babad Wirasaba to increase awareness history against the increasing achievement done by comparing the result of the test value the result of post test using 20 grains about in class experiment (X IPS 4) with class control (X IPS 3). Value post the result of the experiment between class with medium learning that developed.

After the requirements test $\mathrm{T}$ fulfilled, namely test normality and homogenety, so next stage of the test $t$ and independent sample $t$ test. Based on the results of statistical tests with program assistance spss 19 , obtained rerarta post test class experiment of 62.97 and post test class control of 57.35 .Test $t$ from the analysis using spss namely 2.374 with the economic situation of significance much as 0.021 .T count in this analysis is smaller than value of alpha $(\alpha) 0.025(0.021<0.025)$. So can be concluded that $h_{0}$ is rejected or there is a difference between grade rerata experimentation and class control.

The effectiveness of learning history media comic a chronicle wirasaba done with compares the results the post test class experiment ( $\mathrm{x}$ ips 4 ) with the post test class control ( $\mathrm{x}$ ips 3 ). The test results post between grade experiment and class control than among to test average comparison between grade to the media learning developed to see the difference between average class experiment and class control

After the requirements $t$ met, namely the normality and the homogeneity, so the next stage of the test $t$ and independent sample $t$ test. Statistically with program assistance spss 19 , obtained average post experiment test class of 128.06 and post test class of 113.50 control. Test $t$ from the analysis using spss 8.484 with the standard 0.000 significance. T count in this analysis is smaller than value of alpha $(\alpha)$ $0.025(0.000<0.025)$. It can be argued that $h_{0}$ rejected or average there is a difference between grade experiment and class control.

The results of testing is indicated that the use of comic history a Babad wirasaba as a source of independent study students managed to improve value attitude awareness history local students. The difference of the results pretest class experimentation and post test class experiment show there is the increase in the final result. Students is increasingly better significant. Compared with the results of testing dikelas control, the results of class experiment more visible significant. It they in accordance with the research of the Beth Rajan Sockman, Rhonda Sutton, and Michele Herrmann [5]. Comic Relief: Graduate Students Address Multiple Meanings for Technology Integration with Digital Comic Creation (2013).

Researchers develop a research product that serves a source of independent learning and it is expected to build character and historical awareness of student. Through the babad values that appear as learning for students this comic book emerges as a new innovation. Teachers at SMA Negeri 1 Bukateja also is not too difficult to apply this historical comic in the learning process, because this product is easy and practical in its use. Wirasaba historical comic is able to reconstruct historical events for high school students.

The success of comics in teaching and learning activities that it can be adopted as independent learning resources for students that can be proven also with research from San-ao Xia [6]. The existing learning in China is successful and effective to increase student interest. Starting from a high learning interest, then the contents of comics that are rich in historical awareness values will be absorbed by students. 
It can be concluded that the development of instructional media using ADDIE model proved effective. A coherent and clear development procedure allows developers to know what to do. Although the process is quite long because it must perform repetitive testing and must repeat the previous process if in the next process have problems. However, the resulting product is the best product.

There is also research from Ali Merc, Anadolu [7]. The effect of comic strips on efl reading comprehension proves the comics effectiveness so the role of the comic is dependent on its utilization. Ease in the use of comics to make comics to be flexible depending on the comic maker from what things to be invested in a comic.

The advantage of wirasaba historical comic is an independent learning resource with values that can raise local historical awarness of the students. The attitudes that should be known to students and used as a guide for life and community. There is also learning on how social stratification in the empire. This can be seen from the use of traditional clothing of the sultan's, the sentana, the duke, and soldiers.

This comic also shows a lot of local wisdom from Purbalingga District in particular and the ex-residency of Banyumas in general. Learning the attitudes and values are shown to the reader of the comic clearly and structured. The attraction of wirasaba historical comic will make students into the story. Finally, students feel the contents of the comic are the content of babad wirasa historical scripts.

\section{CONCLUSION}

The education role in the globalization era is very important to maintain the existence of the historical awarness values of students. The purpose of historical teacher has aimed to achieving Minimization Criterion Completeness (KKM). The attitude of students' historical awareness is not taken into account, but it is the main thing to form the nation character. The use of Babad Wirasaba historical comis has proven to be effectively used by teachers as a source of independent learning. The development of instructional media using the ADDIE model proved to be effective. A coherent and clear development procedure allows developers to know what to do. Although the process is quite long because it must perform repetitive testing and must repeat the previous process if in the next process have any problems. However, the resulting product is the best product. The advantage of babad wirasaba historical comic is an independent learning resource with values that can raise the students' local historical awarness. The attitudes that should be known to students and used as a guide for life and community. The results of test the effectiveness of show that the use of comic history a Babad wirasaba as a source of independent study students managed to improve value attitude awareness history local students .The difference of the results pretest class experimentation and post test class experiment show there is the increase in the final result .Students is increasingly better significant .Compared with the results of testing class control, the results of class experiment more visible significant.

\section{REFERENCES}

[1] Abdullah, Irwan. (2006). Konstruksi dan Reproduksi Kebudayaan. Yogyakarta: Pustaka Pelajar. 
[2] Azizy, A. Q. (2004). Melawan Globalisasi. Yogyakarta: Pustaka Pelajar.

[3] Mulyorejo. (1956). Naskah Babad Sejarah Wirasaba (Salinan). Wirasaba, Purbalingga.

[4] Molenda, Michael dan Elizabeth Bolingn. (2008). Educational Technology. A Definition with Commentary. New York: Lawrance Erlbaurn Associates.

[5] Sockman, B. R. Sutton, R., dan Michele Herrmann. (2016). Comic Relief: Graduate Students Address Multiple Meanings for Technology Integration with Digital Comic Creation. AECT (Association for educational communications \& technology) Edisi 2016 60:475-485.

[6] San-ao Xia, Hunan University of Science and Engineering, Yongzhou China. 2013. Adoption og Flash cartoon in multy-media teaching system. Applied Mechanics and Materials. Vol 321-324.

[7] Merc, Ali. (2013) Anadolu University Turkey dengan judul penelitian The effect of comic strips on efl reading comprehension. Ijonta. Januari 2013 Volume 4 Issue: 1.

[8] Aman. (2011). Model Evaluasi Pembelajaran Sejarah. Yogyakarta: Ombak.

[9] Atmo, Tri dan Sasono. (1993). Mengenal Purbalingga. Jakarta: Paguyuban Arkakusuma.

[10]Borg, W.R. and Gall, M. D. (1983). Educational Research: An Introduction. London: Longman, inc.

[11] Herusatoto, Budiono. (2008). Banyumas: sejarah, budaya, bahasa, dan watak. Yogyakarta: Lkis.

[12] Kartodirdjo, Sartono. (1990). Sejarah Pergerakan Nasionalisme Indonesia: Dari KolonialismeNasionalisme. Jakarta: Gramedia.

[13] Soedjatmoko, dkk. (1995). Historiografi Indonesia Sebuah Pengantar. Jakarta: PT. Gramedia Pustaka Utama.

[14] Sugiyono. (2011). Metode Penelitian Kuantitatif Kualitatif dan R\&D. Bandung: Alfabeta.

[15] Syah, Muhibin. (2002). Psikologi Pendidikan dengan Pendekatan Baru. Rev.ed. Bandung: Remaja Rosdakarya.

[16] Widja, I Gde, (1989). Pengantar Ilmu Sejarah: Sejarah dalam Perspektif Pendidikan. Semarang: Satya Wacana.

[17] Waluyanto, D. H., (2005). "Komik sebagai Media Komunikasi Visual Pembelajaran”. NIRMANA. Vol. 7, No. 1 Januari 2005: 45-55. 